\title{
Comparison of Small Intestinal Mucosa of Broiler Chicken Fed With Centrosema (Centrosema pubescens L.) Leaf Meal
}

\author{
Marcos Joker Lamire Marcos, Jojo Danao Cauilan, Dunstan Rodney Anolin Galam, and Alford Glenn \\ Castillo Mangoba
}

\begin{abstract}
A total of one hundred and twenty (120) day old chicks were carried out in a Completely Randomized Design to compare the intestinal villi height, villi width and crypt depth of broiler chicken fed with centrosema ( $C$. pubescens) leaf meal at dietary levels of $0,2,4$ and $6 \%$ respectively. The results showed that broiler's duodenal villi height was longest for broilers without leaf meal (T1) $1738.69 \mu \mathrm{m}$ and the shortest for the broilers supplemented with $6 \% \mathrm{C}$. pubescens leaf meal (T4) $883.10 \mu \mathrm{m}$. Duodenum villi width in broilers Treatment 4 had the longer and wider intestinal segments than those broilers in $\mathrm{T} 2$. Crypth depth of $\mathrm{T} 2$ were not significantly deeper $(838.55 \mu \mathrm{m})$ over those broilers in Treatment 3 and 4 and the control group (T1). Jejunal villi height of the broilers supplemented with $2 \%$ C. pubescens leaf meal had the longest villi height in $T 2(1195.79 \mu \mathrm{m})$ and the shortest was measured on T4 $(912.05 \mu \mathrm{m})$. Treatment 3 broilers had wider jejuna villous over those broilers in Treatments 4,2 and 1 respectively. The jejunal crypt depth were deepest on $\mathrm{T2}$ $(362.45 \mu \mathrm{m})$ and the shallowest was recorded on $\mathrm{T} 4$ broilers with $255.82 \mu \mathrm{m}$. T1 the control group had the tallest ileum villi height over those broiler treated or supplemented with $C$. pubescens leaf meal. Broilers in T3 had wider ileum villous with $109.46 \mu \mathrm{m}$ while narrower villi width was observed in $\mathrm{T} 2$ broilers with $66.86 \mu \mathrm{m}$. Treatment 3 were the deepest ileum crypth depth with $362.40 \mu \mathrm{m}$ and the shallowest was measured on (T4) $(259.23 \mu \mathrm{m})$. The inclusion of the different levels of centrosema leaf meal (CLM) did not influenced the growth performance of broiler, however the supplementation of centrosema leaf meal (CLM) on the diet tend to increased body weight of the broiler chicken with the highest rates at $T 3$. The effect of dietary supplementation on the intestinal villi of broilers did not show any variation in terms of the villi height, villi width and crypt depth and results were in congruence with the result of growth rate, feed conversion efficiency and feed conversion ratio.
\end{abstract}

The dietary supplementation of $\mathrm{C}$. pubescens in broiler chicken rations can be add as protein supplement in broilers diet although not significantly different with the use of commercial feeds, addition of CLM in the ration can be advantageous in minimizing production cost.

It is recommended to conduct further studies using higher levels $\mathrm{C}$. pubescens and also the use of colored broiler chickens.

Published on November 28, 2019

Mark Joker Lamire Marcos, Department Of Animal Science And Animal Husbandry, College Of Agriculture, Isabela State University, Philippines. (e-mail: marcos.joker1988@gmail.com)

Jojo Danao Cauilan, School of Veterinary Medicine, Isabela State University, Philippines. (e-mail: jdcauilan@up.edu.ph)

Dunstan Rodney Anoling Galam, Municipal Livestock Inspector, Local Government Unit Of Jones, Isabela, Philippines.

(e-mail: dunstanrodney@yahoo.com).

Alford Glenn Castillo Mangoba, Department Of Animal Science And Animal Husbandry, College Of Agriculture, Isabela State University, Philippines, (e-mail: angobaalfordglenn@gmail.com)
Index Terms-Broiler, Performance, Small Intestines, Villi Height

\section{INTRODUCTION}

Perceptions of consumers on raw and cooked meat quality have created significant interest in increasing the understanding of digestive physiology and the dynamics of the gut microflora [5]. Physiological studies reveal that a functional gastrointestinal tract (GIT) is vital for the digestion and absorption of nutrients required for the bird's maintenance and growth [17], [1]. Gut integrity, its absorptive capacity and subsequent bird performance are improved by access to feed and water immediately post hatch, accompanied by intake of exogenous feed. Without a healthy gut, the best feed can be formulated, but does not ascertain optimal broiler performance [42]. The surface area of the intestinal lining (mucosa) is greatly expanded owing to finger-like projections called villi, which in the avian gut exist throughout the length of the small and large intestines, steadily decreasing in height along the way [14].

The digestive tract is the main site for digestion and absorption of nutrients in the animal. It also acts as the largest immunological organ in the body, as it is the first point of protection against exogenous pathogens that enter the body, preventing the pathogens from colonisation and entering the host cells and tissues [3]. A balanced gut microorganism population, consisting of less pathogenic bacteria, and an increase in beneficial bacteria, may result in an increase in the availability of nutrients [12]. Previously, antibiotics were added to the diets of production animals, and improved the growth rate of these animals by improving their gut health. All in-feed antibiotics have been banned in the European Union since 2006 [5], due to the risk of residue transfer to animal products as well as the production of an antibiotic resistant bacterial population. This has led to the search for an alternative feed additives and safe replacement for in-feed antibiotics.

A number of additives from plants have been reported to contain nutrient properties that affect gut microflora, intestinal morphology and meat quality of poultry. One of the possible sources of cheap protein is the leaf meal of some tropical legumes and browse plants to boost their income through poultry business [36]. Leaf meal supplements have been also included into the diets of poultry birds as a means of increasing weight, improved gut health and thereby reducing cost of production [21]; [8]; [22]. Several leaf meals such as Moringa oleifera, Mungbean, Leucaena, Amaranthus, and among others have been previously reported as feed diets both for poultry and livestock. Studies reported that leaf meals do not only serve as protein source but also provide some necessary vitamins 
and minerals which cause yellow color of broiler skin, shank and egg yolk.

Centrosema pubescens has a dry matter of $57.7 \%$, ash $5.48 \%, 21.0 \%$ crude protein, crude fibre of $8.52 \%$ and a metabolizable energy (Mcal $/ \mathrm{kg}$ ) of 0.41 growth [24] are commonly found in the tropics. Being a leguminous plant, it can be used as livestock feed addictive. The abundance of these succulent leguminous plants around homestead and villages that contain reasonable levels of certain valuable nutrients appears not to have been fully explored. It is believed that the use of such locally abundant green leaves as feed supplements without doubt can improve the performance of poultry birds through enhanced growth [24].

In monogastric animals, dietary fibre content is the main substrate for bacterial fermentation because it cannot be hydrolysed by endogenous enzymes [19]. Qualitative and quantitative microbial colonization begin soon after birth, and develop gradually with age, rendering the maternal intestinal flora and surroundings as the main bacterial proliferation sources to the new-born digestive system [10]; [34]. At this stage, this is a crucial process for all growing animals. However, in commercially bred poultry the process of intestinal microflora development is delayed because of the lack of natural contact between chicks and mother hens. Consequently, the digestive tract becomes burdened with distinguishing between nutrients and nonpathogenic microorganisms from harmful microorganisms while ensuring good nutrient absorption, but excluding digestive microorganisms, harmful and non-harmful [10], [10].

Crypts are indentations into the mucosal layer, which lie next to the villi, and are responsible for the production of enterocytes and goblet cells [30]. As the enterocytes migrate up the villi, where they are eventually sloughed into the lumen, they undergo different functional changes, from having a secretory function in the crypts, to an absorptive function as they travel up the villi [37]. The villi height and crypt depth plays an important role in the digestion and absorption of feed in the small intestine, as an increase in crypt depth and a decrease in villi height can lead to increase secretions into the gastrointestinal tract, resulting in diarrhoea, decrease in disease resistance and decreased animal performance [25]; [2]. The longer the villi, the larger the surface area there is available for absorption of nutrients [30]; [29], due to the increase in number of enterocytes along the villi in the absorptive phase [3]. Shallower crypts are associated with a lower tissue turnover, and therefore less demand for new tissue. This also results in less enterocytes in the secretory stage, therefore less secretions, and more villi enterocytes along the longer villi with absorptive functions, resulting in better nutrient absorption [29]. Therefore, the villi to crypt ratio of the small intestine, plays an important role in the absorptive ability and digestive capacity of the small intestine [29]. According to [30], the ideal villi height and crypt depth of the jejunum for healthy poultry, is $612 \mu \mathrm{m}$ and $188 \mu \mathrm{m}$, respectively. Therefore the optimal healthy villi height to crypt depth ratio for the jejunum is 3.26 .

Thus, further exploration of such morphological changes in gastrointestinal tissues, which are supposedly caused by plant feed additives, could provide further information on possible benefits to the digestive tract [40]; [15]. Hence, this study was conducted to compare the intestinal villi height and evaluate the performance of broiler chicken fed with centrosema (Centrosema pubescens L.) leaf meal.

\section{MATERIALS AND METHODOLOGY}

This study was conducted at the Animal Science Experimental Research Area, College of Agriculture, Isabela State University, Echague, Isabela. A total of 120 day-old chicks were used in a completely randomized design having four treatments $0,2 \%, 4 \%$ and $6 \%$ and three replication with 10 birds per replication. The broilers were raised under intensive management system and fed commercial chick booster from day-old until 7 days old, starter mash from Day 8 until Day 21 (Table 1) and finisher mash from Day 22 until Day 42 (Table 2), before commencement of the experiment. Feed and water were supplied ad libitum. At six (6) weeks of age, six (6) birds were randomly selected per treatment, two per replicate, and fasted for six hours, with water offered ad libitum. Bodyweight was recorded per bird before they were manually slaughtered. Birds were exsanguinated by a unilateral neck that severed the right carotid and jugular vein. After bleeding, scalding, plucking and washing, the feet and head were removed. Carcasses were eviscerated manually and the internal organs were removed. The small intestine was separated into duodenum (from gizzard outlet to the end of the pancreatic loop), jejeunum (from pancreatic loop to Meckel's diverticulum) and ileum (from Meckel's diverticulum to the caecal junction). The samples collected were stored in $10 \%$ neutral buffered formalin over 24 hours and to be processed using the Routine Paraffin Technique. For each intestinal segment, a 2- $\mu \mathrm{m}$ section was placed into a glass slide and it was stained. Slides was viewed on the microscope and visual measurements were taken of the villous height or length ( $\mu \mathrm{m}$ : distance from apex of the villus to the junction of the villus and crypt) and villous width $(\mu \mathrm{m}$ : distance from the junction to the basement membrane of the epithelial cell at the bottom of the crypt.

Table 1. The composition and calculated nutrient analysis of starter formulated ration used in the study

\begin{tabular}{lllll}
\hline Ingredients & $\mathrm{T} 1$ & $\mathrm{~T} 2$ & $\mathrm{~T} 3$ & $\mathrm{~T} 4$ \\
\hline CLM & 0 & 2 & 4 & 6 \\
Rice Bran & 8 & 7.5 & 7.5 & 7.3 \\
Corn meal & 50.9 & 50.15 & 49.15 & 48.12 \\
SBOM & 30.7 & 29.95 & 28.95 & 28.05 \\
Fish meal & 5 & 5 & 5 & 5 \\
Molasses & 2 & 2 & 2 & 2 \\
Salt & 0.5 & 0.5 & 0.5 & 0.5 \\
Vit/Min Premix & 0.5 & 0.5 & 0.5 & 0.5 \\
Methionine & 0.1 & 0.1 & 0.1 & 0.1 \\
Dicaphos & 0.9 & 0.9 & 0.9 & 0.9 \\
Toxin binder & 0.2 & 0.2 & 0.2 & 0.2 \\
\hline Total & 100 & 100 & 100 & 100 \\
\hline
\end{tabular}

Calculated analysis

\begin{tabular}{lcccl}
\hline CP $(\%)$ & 20.67 & 20.63 & 20.53 & 20.47 \\
ME (Kcal) & $2,839.38$ & 2844.18 & 2846.78 & 2850.26 \\
Calcium & 1.06 & 1.06 & 1.05 & 1.04 \\
Avail P & 0.43 & 0.42 & 0.42 & 0.42 \\
Methionine & 0.44 & 0.44 & 0.43 & 0.43 \\
Lysine & 1.20 & 1.18 & 1.15 & 1.12 \\
\hline
\end{tabular}


Table 2. The composition and calculated nutrient analysis of finisher formulated ration used in the study

\begin{tabular}{lllll}
\hline Ingredients & T1 & T2 & T3 & T4 \\
\hline CLM & 0 & 2 & 4 & 6 \\
Rice Bran & 8.3 & 8 & 8 & 7.5 \\
Corn meal & 50.6 & 50 & 48.8 & 48.3 \\
SBOM & 30.4 & 29.7 & 28.8 & 28.3 \\
Fish meal & 5.3 & 5 & 5 & 5 \\
Molasses & 2 & 2 & 2 & 2 \\
Salt & 0.5 & 0.5 & 0.5 & 0.5 \\
Vit/Min Premix & 0.5 & 0.5 & 0.5 & 0.5 \\
Methionine & 0.1 & 0.1 & 0.1 & 0.1 \\
Dicaphos & 0.9 & 0.9 & 0.9 & 0.9 \\
Toxin binder & 0.2 & 0.2 & 0.2 & 0.2 \\
\hline Total & 100 & 100 & 100 & 100 \\
\hline
\end{tabular}

Calculated analysis

\begin{tabular}{lccrr}
\hline CP $(\%)$ & 19.73 & 19.58 & 19.51 & 19.30 \\
ME (Kcal) & 2837.85 & 2845.38 & 2843.52 & 2848.67 \\
Calcium & 1.07 & 1.06 & 1.05 & 1.02 \\
Avail P & 0.43 & 0.42 & 0.42 & 0.40 \\
Methionine & 0.45 & 0.43 & 0.43 & 0.41 \\
Lysine & 1.21 & 1.17 & 1.15 & 1.11
\end{tabular}

Data collection: Measurement of Villus Height, Width and Crypt Depth. Villi was selected from each section (2 villi per section) that demonstrated the longitudinal view from base to tip. The villus height was measured from the tip to the bottom excluding the crypt, while the villus width was measured at the basal and apical parts. The growth performance of the broiler was evaluated on a weekly basis body weight and feed consumption. However, gain in weight, feed conversion ratio and efficiency (FCR/FCE) and growth rate was calculated.

Statistical analysis: All data gathered were subjected to Analysis of Variance of Completely Randomized Design and comparison of treatment means was done using Least Significant Difference (LSD) Test. Analysis was carried out using the Statistical Tool for Agricultural Research (STAR) 2.0.1.

\section{RESULTS}

Table 3. Means $(\mu \mathrm{m})$ of duodenal villi height, villi width and crypt depth of broiler chicken fed with centrosema (Centrosema pubescens) leaf meal

\begin{tabular}{cccc}
\hline \hline & \multicolumn{3}{c}{ DUODENUM } \\
\cline { 2 - 4 } TREATMENTS & $\begin{array}{c}\text { Villi } \\
\text { height }\end{array}$ & $\begin{array}{c}\text { Villi } \\
\text { width }\end{array}$ & $\begin{array}{c}\text { Crypt } \\
\text { depth }\end{array}$ \\
\hline T $_{1}$-Control & 1738.69 & 92.58 & 668.91 \\
$\mathrm{~T}_{2}-2 \%$ CLM & 979.97 & 79.34 & 838.55 \\
$\mathrm{~T}_{3}$ - 4\% CLM & 998.42 & 85.49 & 488.04 \\
$\mathrm{~T}_{4}-6 \%$ CLM & 883.10 & 108.02 & 527.65 \\
\hline ANOVA & $\mathrm{ns}$ & $\mathrm{ns}$ & $\mathrm{ns}$ \\
\hline C.V. (\%) & 31.83 & 23.51 & 50.96 \\
\hline
\end{tabular}

ns $=$ not significant
Table 4. Means $(\mu \mathrm{m})$ of jejunum villi height, villi width and crypt depth of broiler chicken fed with centrosema (Centrosema pubescens) leaf meal

\begin{tabular}{cccc}
\hline \hline \multirow{2}{*}{ TREATMENTS } & \multicolumn{3}{c}{ JEJUNUM } \\
\cline { 2 - 4 } & $\begin{array}{c}\text { Villi } \\
\text { height }\end{array}$ & Villi width & $\begin{array}{c}\text { Crypt } \\
\text { depth }\end{array}$ \\
\hline $\mathrm{T}_{1}$-Control & 1081.54 & 77.70 & 275.46 \\
$\mathrm{~T}_{2}-2 \%$ CLM & 1195.79 & 76.14 & 362.45 \\
$\mathrm{~T}_{3}$ - 4\% CLM & 1141.68 & 113.62 & 324.84 \\
$\mathrm{~T}_{4}-6 \%$ CLM & 912.05 & 67.60 & 255.82 \\
\hline ANOVA & $\mathrm{ns}$ & $\mathrm{ns}$ & $\mathrm{ns}$ \\
\hline C.V. $(\%)$ & 33.07 & 46.44 & 33.87 \\
\hline
\end{tabular}

$\mathrm{ns}=$ not significant

Table 5. Means $(\mu \mathrm{m})$ of ileum villi height, villi width and crypt depth of broiler chicken fed with centrosema (Centrosema pubescens) leaf meal

\begin{tabular}{cccc}
\hline \multirow{2}{*}{ TREATMENTS } & \multicolumn{3}{c}{ ILEUM } \\
\cline { 2 - 4 } & $\begin{array}{c}\text { Villi } \\
\text { height }\end{array}$ & $\begin{array}{c}\text { Villi } \\
\text { width }\end{array}$ & $\begin{array}{c}\text { Crypt } \\
\text { depth }\end{array}$ \\
\hline $\mathrm{T}_{1}$-Control & 800.89 & 68.47 & 293.14 \\
$\mathrm{~T}_{2}-2 \%$ CLM & 619.47 & 66.86 & 337.20 \\
$\mathrm{~T}_{3}$ - 4\% CLM & 777.91 & 109.46 & 362.40 \\
$\mathrm{~T}_{4}-6 \%$ CLM & 789.46 & 71.75 & 259.23 \\
\hline ANOVA & $\mathrm{ns}$ & $\mathrm{ns}$ & $\mathrm{ns}$ \\
\hline C.V. $(\%)$ & 18.10 & 45.57 & 45.82 \\
\hline
\end{tabular}

$\mathrm{ns}=$ not significant

Table 6. Production performance of broiler chicken fed with centrosema (C. Pubescens) leaf meal

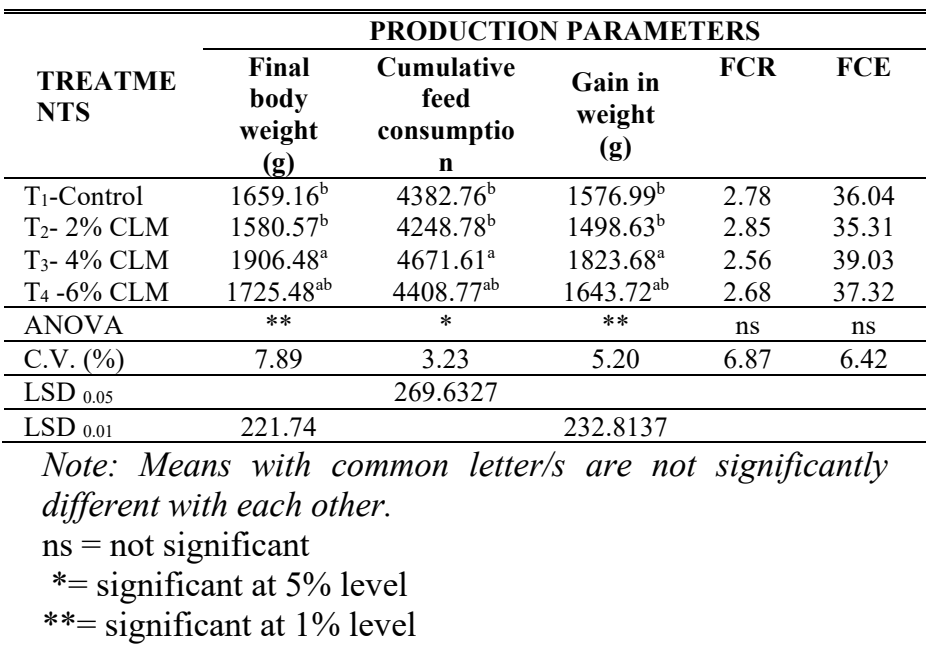

\section{DISCUSSION}

Histology of the Mucosal Surface of All Segments of the Small Intestine in Broilers.

Histological study of the mucosal surface of all segments of the small intestine in broilers were conducted including the measurement of the villi height, villi width and crypt depth.

The Duodenal Villi Height, Villi Width and Crypt Depth of Broiler Chicken Fed with Centrosema (Centrosema 
pubescens) Leaf Meal is presented in Table 4. No significant differences were observed on duodenal villi height, villi width and crypth depth of broiler chickens were observed. The villi height is longest for the broilers on the control group (T1) with a mean value of $1738.69 \mu \mathrm{m}$ and shortest for the broilers supplemented with $6 \% \mathrm{C}$. pubescens leaf meal (T4) with a mean of $883.10 \mu \mathrm{m}$. In terms of the duodenum villi width, broilers supplemented with $6 \% \mathrm{C}$. pubescens leaf meal (T4) is the widest among all treatments with a mean of $108.02 \mu \mathrm{m}$ than those broilers in T2 with $2 \%$ C. pubescens leaf meal with a mean of $79.34 \mu \mathrm{m}$. In terms of crypt depth, no significant difference among treatments were observed. Statistically, T2 with $2 \%$ C. pubescens leaf meal were not significantly deeper $(838.55 \mu \mathrm{m})$ over those broilers supplemented $4 \%$ (T3), $6 \%$ (T4) C. pubescens leaf meal and the control group (T1). Although results showed a not significant difference on the villi height, villi width and crypt depth on all treatments, it can be noted that in all treatments supplemented with C. pubescens leaf meal, T3 had the tallest villi height and the shallower crypt depth. Tall villi height and shallow crypt depth indicates that intestinal segments in T3 has more absorptive cells and also a slow turnover of secretory cells from the intestinal crypt which shows an efficient absorption of nutrients in this segment when compared with other treatment groups. The epithelial cells lining the villi facilitate the absorption of fluids and nutrients, secrete electrolytes and fluids, and regenerate and replace damaged cells or those lost to normal attrition [14]. This is also in congruent with the result of feed conversion ratio and feed conversion efficiency of broilers in $\mathrm{T} 3$ as shown in Table 6, where T3 has the lowest feed conversion ratio and has the highest feed conversion efficiency.

The Jejunal Villi Height, Villi Width and Crypth Depth of Broiler Chicken Fed with Centrosema (Centrosema pubescens) Leaf Meal is presented in Table 5. Nonsignificant differences among treatment groups were observed in terms of villi height, villi width and crypt depth of broiler chicken. It was also noted that the jejunal villi height of the broilers supplemented with $2 \% \mathrm{C}$. pubescens leaf meal (T2) had the tallest villi height with a mean of $1195.79 \mu \mathrm{m}$ and the shortest was measured on T4 with $6 \%$ C. pubescens leaf meal $912.05 \mu \mathrm{m}$. Boilers in Treatment 3 had the broadest villous width compared over those broilers in Treatments 4, 2 and 1 respectively. The jejunum crypt depth were deepest on broilers in T2 supplemented with $2 \%$ C. pubescens leaf meal with a mean of $362.45 \mu \mathrm{m}$ and the shallowest was recorded on T4 broilers supplemented with 6 $\%$ C. pubescens leaf meal with a mean value of $255.82 \mu \mathrm{m}$.

Although non-significant difference was observed, in terms of villus surface area considering the villi height and width, boilers in $\mathrm{T} 3$ had the highest surface area which indicates an efficient nutrient absorptive capacity.

The Ileum Villi Height, Villi Width and Crypt Depth of Broiler Chicken Fed with Centrosema (Centrosema pubescens) Leaf Meal is presented in Table 6. No significant differences were observed among treatment groups in terms of ileum villi height, villi width and crypt depth of the broiler chicken. Broilers in T1 (control group) had the tallest villi height with a mean value of $800.89 \mu \mathrm{m}$ when compared over those broiler treated or supplemented with C. pubescens leaf meal with means of $619.47 \mu \mathrm{m}$ (T2) , 777.91 $\mu \mathrm{m}$ (T3) and $789.46 \mu \mathrm{m}$ (T4). Broilers in T3 had broader villous width a means of $109.46 \mu \mathrm{m}$ while narrow villi width was observed in T2 broilers with means of $66.86 \mu \mathrm{m}$. with regards to crypt depth, broilers in Treatment 3 had the deepest crypt depth with a mean of $362.40 \mu \mathrm{m}$ and the shallowest was measured on broilers supplemented with $6 \%$ C. pubescens leaf meal (T4) with a mean value of 259.23 $\mu \mathrm{m}$.

Although non-significant difference was observed, in terms of villus surface area considering the villi height and width, broilers in $\mathrm{T} 3 \mathrm{had}$ the highest surface area which indicates an efficient nutrient absorptive capacity, however, this is in contrast with the result of crypt depth where rapid crypt stem cell turnover is possible which is indicated by the having a deeper crypt depth. Although not consistently observed.

In general, villi height morphology in the segments of the small intestinal, the duodenum has the tallest villi among the three segments with the ileum having the shortest villi ideally. However, in the present study, the jejunal segment has the tallest villi height when compared to the duodenum. The jejunum is largely responsible for digestion and absorption of all the major nutrients. Thus, increased villi height may be a consequence of greater need for digestive capacity [35].

The result of the study shows a non-significant difference among all treatment groups on the villi height, villi width and crypt depth of all the segments of the small intestine. In terms of the villus surface area (villi height and villi width), broilers in Treatment 3 has the greatest surface area when compared with Treatments 1,2 and 4 for the jejunal and ileal segments of the small intestine. In the duodenal region, T3 has a taller villi height and shallowest crypt depth when compared with treatments 2 and 4 which indicates efficiency in the absorption of nutrients.

\section{Growth Performance of the Broiler Chicken}

The production performance of broiler chicken fed with Centrosema (C. pubescens) in terms of the final body weight, cumulative feed consumption, gain in weight, feed conversion ratio and efficiency are shown in Table 7.

Significant result was obtained on the final body weight of Broilers in Treatment 3 when compared with Treatments 1 and 2 while it is comparable with Treatment 4 . No significant difference was observed in Treatments 1,2 and 4.

In terms of the cumulative feed consumption of the broiler chickens, significant result was obtained on the final body weight of Broilers in Treatment 3 when compared with Treatments 1 and 2 while it is comparable with Treatment 4. No significant difference was observed in Treatments 1, 2 and 4.

Significant result was obtained on the gain in weight of 
Broilers in Treatment 3 when compared with Treatments 1 and 2 while it is comparable with Treatment 4 . No significant difference was observed in Treatments 1, 2 and 4. The significantly higher weight gained on the different treatments, however it was attributed mainly on the higher nutrient intake of birds as revealed on the weekly feed consumed of the experimental treatments. Moreover the results revealed that broilers fed with centrosema leaf meal significantly affect the gain in weight of the broilers at Treatments 3 and 4 .

In terms of the feed conversion ratio, it can be noted that a non-significant result among treatments were observed as revealed by analysis of variance. Feed conversion ratio is lowest in broilers fed with $4 \%$ CLM (T3) and highest at broilers fed with $2 \%$ CLM (T2) with an average ratio of 2.56 (T3) to 2.85 (T2), respectively.

On the other hand, the feed conversion efficiency of the broilers, the results of the study revealed insignificant differences among treatment were observed. Numerically the broilers had an average efficiency mean from 35.31 to 39.03. Feed conversion efficiency is lowest in broilers fed with 4\% CLM (T3) and highest at broilers fed with $2 \%$ CLM (T2) with an average efficiency mean of 35.31 (T3) to 39.03 (T2), respectively.

\section{CONCLUSION AND RECOMMENDATION}

The inclusion of the different levels of centrosema leaf meal (CLM) did not influenced the growth performance of broiler, however the supplementation of centrosema leaf meal (CLM) on the diet tend to increased body weight of the broiler chicken with the highest rates at T3. The effect of dietary supplementation on the intestinal villi of broilers did not show any variation in terms of the villi height, villi width and crypt depth, however, results are in congruence with the result of growth rate, feed conversion efficiency and feed conversion ratio.

The dietary supplementation of C. pubescens in broiler chicken rations clearly indicates that CLM can be add as protein supplement in broilers diet although not significantly different with the use of commercial feeds, addition of CLM in the ration can be advantageous in minimizing production cost.

\section{ACKNOWLEDGMENT}

The authors would like to thank the Animal Science Department, College of Agriculture and the School of Veterinary Medicine, Isabela State University, Echague, Isabela for the support and allowing the researchers to conduct their research study.

\section{REFERENCES}

[1] Baurhoo, B., Ferket, P.R. \& Zhao, X., 2009. Effects of diets containing different concentrations of mannan oligosaccharide or antibiotics on growth performance, intestinal development, cecal and litter microbial populations, and carcass parameters of broilers. Poult. Sci. 88, 22622272 .
[2] Catalá-Gregori, P., Mallet, S., Travel, A., Orengo, J. \& Lessire, M., 2008. Efficiency of a prebiotic and a plant extract alone or in combination on broiler performance and intestinal physiology. Canadian Journal of Animal Science, 88, 623-629.

[3] Choct, M., 2009. Managing gut health through nutrition. British Poultry Science, 50, 9-15.

[4] Devendra AM., O' Mello JP (2014) The use of tree crops and their byproductsfor intensive animal production. Trop Anim Hlth and Prod 31: 295-305.

[5] Dibner, J.J. \& Richards, J.D., 2005. Antibiotic growth promoters in agriculture: history and mode of action. Poult. Sci. 84, 634-643.

[6] D'Mello JPF (1995) Leguminous leaf meals in non-ruminant nutrition. In: D'Mello JPF \& Devendra C (Eds.) Tropical Legumes in Animal Nutrition. CAB International, Wallingford, UK. Pp. 247 -280 .

[7] Emmanuel EB., (2005) A compendium of agricultural crops and common weeds in Akwa Ibom State of Nigeria. Robert Minder Publication Ltd. Uyo, Nigeria, Pp. 150.

[8] Esonu BD, Iheukwumere FC, lwuji TC, Akanu N, Nwugo OH (2003) Evaluation of Microdesmis puberula leaf meal as feed ingredient in broiler starter diets. Nigerian Journal of Animal $\begin{array}{llllll}\text { Production } & 30: & 3 & - & 8 .\end{array}$ http://dx.doi.org/10.4314/njap.v30i1.3306.

[9] Food and Agricultural Organization of the United Nations. "Centrosema pubescens Benth". Rome, 2013. FAO. November 3, 2013.

[10] Fortun-Lamothe, L. \& Boullier, S., 2007. A review on the interactions between gut microflora and digestive mucosal immunity. Possible ways to improve the health of rabbits. Livest. Sci. 107, 1-18.

[11] Germplasm Resources Information Network (GRIN). Agricultural Research Service (ARS), United States Department of Agriculture (USDA). Retrieved 16 January 2018.

[12] Hashemi, S. R. \& Davoodi, H., 2011. Herbal plants and their derivatives as growth and health promoters in animal nutrition. Veterinary Research Communications, 35, 169-180.

[13] Hashemi, S. R. \& Davoodi, H., 2010. Phytogenics as new class of feed additive in poultry industry. Journal of Animal and Veterinary Advances, 9, 2295-2304

[14] Hoerr, F.J., 2001. Intestinal integrity and the impact of losing it. Elanco Poultry Health Conference, Atlanta, January 21st.

[15] Issa, K.J., \& Omar, J.M.A., 2012. Effect of garlic powder on performance and lipid profile of broilers. Open J. Anim. Sci. 2 (2), 62-68.

[16] Leaphart, C.L., \& Tepas III, J.J., 2007. The gut is a motor of organ system dysfunction. Surgery 141 (5), 563569.

[17] Mateos, G.G., La'zaro, R. \& Gracia, M.I., 2002. The feasibility of using nutritional modifications to replace drugs in poultry feeds. J. Appl. Poult. Res. 11, 437-452.

[18] Miles, R.D., Butcher, G.D., Henry, P.R. \& Littell, R.C., 2006. Effect of antibiotic growth promoters on broiler performance, intestinal growth parameters, and quantitative morphology. Poult. Sci. 85, 476-485.

[19] Montagne, L., Pluske, J.R. \& Hampson, D.J., 2003. A review of interactions between dietary fibre and the intestinal mucosa, and their consequences on digestive health in young non-ruminant animals. Anim. Feed Sci. Technol. 108, 95-117.

[20] [20] Nworgu FC, Fapohunda JB (2002) Performance of broiler chicks fed mimosa (Mimosa invisa)leaf meal supplements. Proceeding of 27th Annual Conference of Nigerian Society for Animal Production (NSAP) held at Federal University of Technology Akure on March 17th - 21st, 2002 Pp. 128 - 131.

[21] Nworgu, F.C.; Egbunike, (2013). "Nutritional potential of Centrosema pubescens, Mimosa invisa and Pueraria phaseoloides leaf meals on growth performance responses of broiler chickens". American Journal of Experimental Agriculture. 3 (3): 506-519.]

[22] Nworgu FC, Oduola OA, Alikwe PC, Ojo SJ (2012) Effect of basil (Ocimum gratissimum) leaf supplement on initiation of egg laying and egg quality parameters of growing pullets. Journal of food, Agriculture and Environment 10: 337-342. 
[23] Onyeonagu CC, Eze SM (2013) Proximate compositions of some forage grasses and legumes as influenced by season of harvest African Journal of Agricultural Research 8: 4033-4037.

[24] Offor, US and Wariboko, ON (2013). Effects of leguminous plants (Centrosema pubescens) as feed additive for growth stimulation on broilers. World Journal of Agricultural Sciences Vol.1 (10), pp. 299-302, November 2013.

[25] [25] Parsaie, S., Shariatmadari, F., Zamiri, M. \& Khajeh, K., 2007. Influence of wheat-based diets supplemented with xylanase, bile acid and antibiotics on performance, digestive tract measurements and gut morphology of broilers compared with a maize-based diet. British Poultry Science, 48, 594-600.

[26] Perić, L., Milošević, N., Žikić, D., Bjedov, S., Cvetković, D., Markov, S., Mohnl, M. \& Steiner, T., 2010. Effects of probiotic and phytogenic products on performance, gut morphology and caecal microflora of broiler chickens. Archiv Fur TierzuchtArchives of Animal Breeding, 53, 350-359.

[27] Phuc BHN, Ogle B, Lindbery JE (2001) Nutritive Value of Cassava Leaves for Monogastric Animal. International Workshop on Current research and development in the use of Cassava as Animal Feed, Maryland, USA, Pp. 31-40.

[28] Rocha C., Durau JF, Barrilli LNE, Dahlke F, Maiorka P (2014) The effect of raw and roasted soybeans on intestinal health, diet digestibility, and pancreas weight of broilers. The J Appl Poult Res 23: 71-79.

[29] Saeid, J. M., Mohamed, A. B. \& AL-Baddy, M. A., 2013. Effect of adding garlic powder (Allium sativum) and black seed (Nigella sativa) in feed on broiler growth performance and intestinal wall structure. Journal of Natural Sciences Research, 3, 35-41.

[30] Shen, L., 2009. Functional Morphology of the Gastrointestinal Tract in: Molecular Mechanisms of Bacterial Infection Via the Gut. Springer, Heidelberg, Dordrecht, London, New York. pp. 135 .

[31] Slominski BA., (2011) Recent advances in research on enzymes in poultry diets. Poult Sci 90: 2013-2023

[32] Smirnov, A., Tako, E., Ferket, P. \& Uni, Z., 2006. Mucin gene expression and mucin content in the chicken intestinal goblet cells are affected by in ovo feeding of carbohydrates. Poultry Science, 85, 669-673.

[33] Souza, A.C.B; Carvalho, Ramos, Campos, Sforça, Zucchi, Jank,Souza (2011). "Genetic studies in Centrosema pubescens Benth, a tropical forage legume: the mating system, genetic variability and genetic relationships between Centrosemaspecies". Euphytica. 181: 223-235. doi:10.1007/s10681-011-0415-0.

[34] Steiner, T. \& Wegleitner, K., 2007. Natural growth promoters for gut health management. World Poult. Mag. 23 (7), 22-24.

[35] Svihus, B., 2014. Function of the digestive system. J. Appl. Poult. Res. 23, 306-314.

[36] Swain BK, Naik PK and Singh NP (2014) Unconventional feed resources for efficient poultry production. Tech Bull 47 ICARICAR Research Complex Goa, India.

[37] Uni, Z., Geyra, A., Ben-Hur, H. \& Sklan, D., 2000. Small intestinal development in the young chick: Crypt formation and enterocyte proliferation and migration. British Poultry Science, 41, 544-551.

[38] Van der Klis, J. \& Jansman, A., 2002. Optimising nutrient digestion, absorption and gut barrier function in monogastrics: Reality or illusion. In: Nutrition and Health on the Gastrointestinal Tract. Eds. Blok, M. C., Vahl, H. A., de Lange, L., van de Braak, A. E., Hemke, G. \& Hessing, M., Netherlands. Pp. 15-36.

[39] WAC (2006) World Agroforestry Centre. Spreading the word about leaf meal. Spore 125:6.

[40] Windisch, W., Schedle, K., Plitzner, C. \& Kroismayr, A., 2008. Use of phytogenic products as feed additives for swine and poultry. J. Anim. Sci. 86, E140-E148.

[41] Xu, Z., Hu, C., Xia, M., Zhan, X. \& Wang, M., 2003. Effects of dietary fructooligosaccharide on digestive enzyme activities, intestinal microflora and morphology of male broilers. Poultry Science, 82, 1030-1036.
[42] Yegani, M., \& Korver, D.R., 2008. Factors affecting intestinal health in poultry. Poult. Sci. 87, 2052-2063.

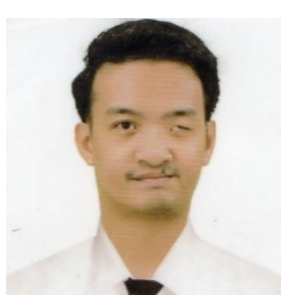

MARK JOKER L. MARCOS, is a graduate of Animal Science at Isabela State University both his Bachelor's and Master's degree and he is also a licensed Agriculturist. Presently, he is employed as Faculty of the Department of Animal Science, College of Agriculture, Isabela State University. As faculty-researcher he is handling and involved in various research work in the University particularly in the field of Small Ruminant and Poultry. Among his research work today is the on-going Externally Funded ItikPINAS project " Evaluation of the Production Performance and Egg Quality of IP Kayumanggi in Selected Duck Egg Producing Regions of the Philippines" under the Philippine Duck Industry-focused Technologies, Innovations and Knowledge for Livelihood Income and Food Supply Enhancement (ITIK for LIFE) Program for Sustainability funded by Department of Science and Technology - Philippine Council for Agriculture, Aquatic and Natural Resources Research and Development (DOST-PCAARRD Mr. Marcos also is an active member of Philippine Association for Agriculturist (PAA), Philippine Society of Animal Science (PSAS), Philippine Association of Extension Program Implementors, Inc. (PAEPI) and Philippine Association for Laboratory Animals (PALAS)

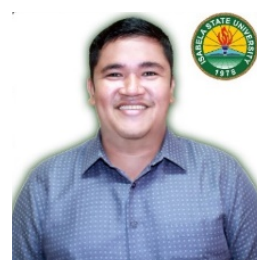

JOJO D. CAUILAN, is a graduate of Doctor of Veterinary Medicine at Cagayan State University in 2005 and he took and passed the veterinary licensure examination on the same year. Currently, he is an Assistant Professor at the School of Veterinary Medicine, Isabela State University. He took his Master of Science in Veterinary Medicine major in Veterinary Anatomy at the University of the Philippines Los Baños in 2018. He is currently working on his research on the field of Veterinary Anatomy which includes the Use of alternative solutions in the preservation of domestic animals for gross dissections studies. He is a member of the Philippine Veterinary Medicine Association, Philippine Association of Veterinary Educators Society, Philippine Association of Laboratory Animal Science and the Philippine Society for Animal Science.

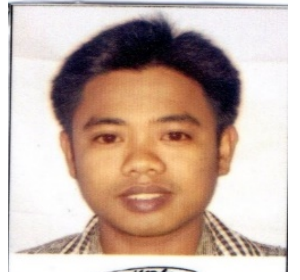

ALFORD GLENN C. MANGOBA, is graduate of BS Agriculture major in Animal Science at the Adventist University of The Philippines, Cavite, Philippines. He took his Master of Science in Animal Science at the Isabela State University. $\mathrm{He}$ is currently working as Instructor at the Department of Animal Science and Animal Husbandry, College of Agriculture, Isabela State University. He is a member of the Philippine Society for Animal Science (PSAS). His field of interest focus on swine production and poultry production.

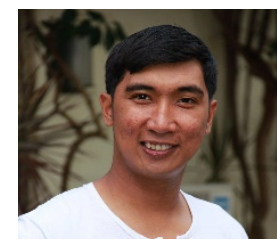

DUNSTAN RODNEY A GALAM is a graduate of Animal Science at the Isabela State University, Echague Isabela both his Bachelor's and Master's Degree. $\mathrm{He}$ is currently employed as Municipal Livestock Inspector at the Local Government Unit of Jones, Isabela. He is also active member of the Philippine Society of Animal Science-Cagayan 